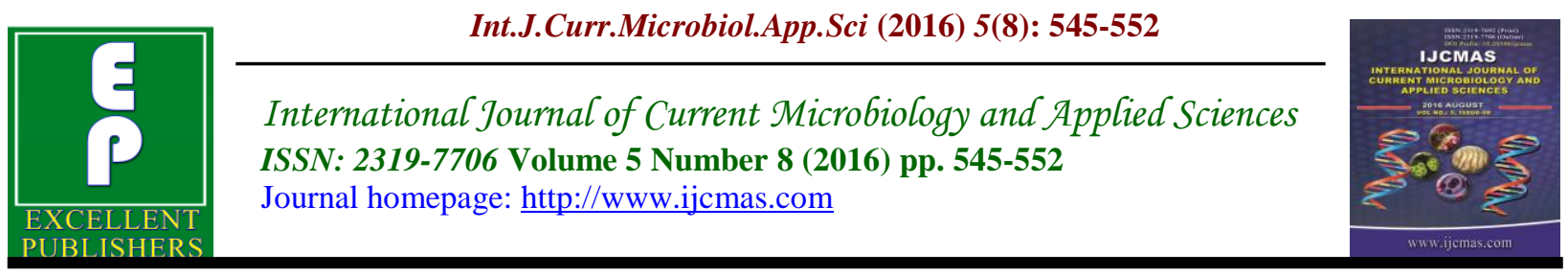

Original Research Article

http://dx.doi.org/10.20546/ijcmas.2016.508.059

\title{
Schiff Base [(N1Z, N2Z)-N1, N2-bis (1-Phenylethylidene) ethane-1, 2-diamine] with P-Hydroxyphenyl Telluriumtribromide and their Metal Complexes: Synthesis and Characterization
}

\author{
Nuha H. Al-Saadawy ${ }^{1 *}$, Allaa Kh. Ali ${ }^{2}$ and Huda J. Mohammed ${ }^{1}$ \\ ${ }^{1}$ Department of Pharmaceutical Chemistry, College of Pharmacy, \\ University of Thi-Qar, Thi-Qar, Iraq \\ ${ }^{2}$ Department of Clinical laboratory sciences, College of Pharmacy, \\ University of Thi-Qar, Thi-Qar, Iraq \\ *Corresponding author
}

\begin{abstract}
A B S T R A C T
Keywords

Complexes, organotellurium, metal complexes, ethylenediamine, acetophenone.

\section{Article Info}

Accepted:

23 July 2016

Available Online:

10 August 2016

The reaction of aliphatic diamine [ethylene diamine] with acetophenone under showed conditions yielded Schiff base ligand. The another ligand ( $p$ hydroxyphenyl telluriumtribromide) has been added to complexes. The structures of $\mathrm{Cu}(\mathrm{II}), \mathrm{Ni}$ (II), $\mathrm{Co}(\mathrm{II}), \mathrm{Zn}$ (II) and $\mathrm{Fe}$ (II) with schiff base compound and organotellurium ligand have been joined by the reacting between copper bromide, hydrate nickel chloride, hydrate cobalt chloride, zinc chloride, and iron bromide and two ligands in 1:2:2 mole ratio. The free ligands and their metal structures have been withdrawn in the solid state. The spectroscopic data of the structures suggest their 1:2:2 buildings structures which are inspected by elemental analysis (CHN), FT-IR, ${ }^{1} \mathrm{H}$ NMR spectroscopy. The spectroscopic studies proposed the octahedral structure for the all structures and the results are represented and analyzed underneath.
\end{abstract}

\section{Introduction}

Schiff bases and their bio-dynamic buildings have been concentrated widely over the previous decade. Schiff bases give potential locales to bio-artificially dynamic mixes. Different move and inward move metal buildings with bi, tri and tetradentate. Schiff bases containing nitrogen and oxygen or sulfur giver particles assume a critical part in organic systems (Malik et al., 2011; Raman et al., 2007). Schiff bases got from an amino and carbonyl compound are an essential class of ligands that direction to metal particles through azomethine nitrogen and have been concentrated widely. In azomethine subordinates, the $\mathrm{C}, \mathrm{N}$ linkage is crucial for natural action, a few azomethine have been accounted for to have amazing antibacterial, antifungal, anticancer and antimalarial activities (Annapoorani et al., 2013). Schiff bases are for the most part bidentate (Hine et al., 1967), tridentate (Fessenden et al., 1998), tetradentate (Cimerman et al., 2000) or polydentate (Elmali et al., 2000) ligands equipped for shaping exceptionally stable edifices with move metals. They can just go about as 
organizing ligands in the event that they bear an utilitarian gathering.

Organochalcogen science has grown quickly in the course of the last few decades (Arnold, 1995; Smith et al., 2000; Levason et al., 2002), and is credited to potential utilizations of organochalcogen mixes experiencing significant change metal catalyzed natural synthesis (Nishibayshi et al., 1996; Wirth, 2000; Kumar et al., 2008; Shi et al., 2007; Tiecco et al., 2004), as single source forerunners in metalorganic concoction vapor testimony (MOCVD) forms for creating materials (Steigerwald et al., 1987; Hirpo et al., 1993; Cheng et al., 1996; Anyfantis et al., 2008), in ligand chemistry (Ling et al., 2007) and biochemistry (Shi et al., 2002; Kanda et al., 1999; Kunwar et al., 2007). Uses of organochalcogen mixes have, be that as it may, been confined by troubles in manufactured procedures, sanitization and dangers of specific subordinates. To beat these challenges, sterically cumbersome substituents and chelating bunches in close closeness to selenium and tellurium have been utilized. Inward chelation has been stretched out to outline and orchestrate ligands containing both ""hard"" and ""soft"" donors (Lloyd et al., 2008; Jones et al., 1996).

\section{Experimental}

\section{Chemicals and Apparatus}

Chemicals acquired from Sigma-Aldrich, Fluka and BDH utilized without filtration. Liquefying point was dictated by utilizing open hairlike tube dissolving point mechanical assembly. 1H NMR spectra was recorded on Bruker $300 \mathrm{MHz}$ spectrometers with TMS as an inner reference utilizing DMSO-d6 dissolvable. Infra-red spectra were recorded with $\mathrm{KBr}$ circles utilizing a FTIR spectrophotometer Shimadzu model $8400 \mathrm{~S}$ in reach $4000-400 \mathrm{~cm}-1$. Essential examination for Carbon, Hydrogen and Nitrogen were performed by utilizing an Euro vector EA 3000A Elemental Analysis (Italy). Dissolving purposes of every single strong compound were resolved utilizing a MPS10 electrically warmed liquefying point mechanical assembly.

\section{Synthesis of Schiff base}

The following compounds were synthesized as described in literature. (4hydroxyphenyl)tellurim tribromide (AlJadaan, 1990) and $\left[\left(\mathrm{N}^{1} \mathrm{Z}, \mathrm{N}^{2} \mathrm{Z}\right)-\mathrm{N}^{1}, \mathrm{~N}^{2}\right.$-bis $(1-$ phenylethylidene)ethane-1,2-diamine] was prepared by the following general method (Deyr et al., 1972).

Preparation of $\operatorname{BAPE}\left(\mathrm{C}_{18} \mathrm{H}_{20} \mathrm{~N}_{2}\right)$ : Acetophenone $(0.1$ mole $)$ and ethylenediamine (0.05 mole) was mixed together in $50 \mathrm{ml}$. of absolute alcohol and refluxed on water bath for about 2 hrs. The pale yellow solution obtained after reflux gave white crystalline compound on standing for 4 days in a vacuum desiccator. It was filtered under suction and washed with alcohol and finally recrystallised from absolute alcohol, yield 81\%, m. p. 109 $111^{\circ} \mathrm{C}$. BAPE is soluble in many organic solvents, but insoluble in water.

\section{Synthesis of $\mathrm{Cu}(\mathrm{II}), \mathrm{Ni}(\mathrm{II}), \mathrm{Co}(\mathrm{II}), \mathrm{Zn}(\mathrm{II})$ and $\mathrm{Fe}(\mathrm{II})$ complexes}

All the new structures were set up by the same methodology: a solution of $\left[\left(\mathrm{N}^{1} \mathrm{Z}\right.\right.$, $\mathrm{N}^{2} \mathrm{Z}$ )- $\mathrm{N}^{1}, \mathrm{~N}^{2}$-bis (1-phenyl-ethylidene) ethane-1,2-diamine] (BAPE) $(1 \mathrm{mmol})$ in absolute ethanol $(10 \mathrm{~mL})$ was added to solution of 4-(hydroxyphenyl) tellurium tribromide (OPTB) $(1 \mathrm{mmol})$ in absolute ethanol $(10 \mathrm{~mL})$ and the mixture was refluxed for $30 \mathrm{~min}$ and then $\mathrm{NiCl}_{2} \cdot 6 \mathrm{H}_{2} \mathrm{O}, \mathrm{CoCl}_{2} \cdot 6 \mathrm{H}_{2} \mathrm{O}, \mathrm{CuBr}_{2}, \mathrm{ZnCl}_{2}$ or $\mathrm{FeBr}_{2}(0.5 \mathrm{mmol})$ in absolute ethanol $(10 \mathrm{~mL})$ was added to the ligand solution with stirring and the reaction mixture was 
further stirred under reflux for $3 \mathrm{hrs}$.

The obtained colored solution was left standing at room temperature to crystallize. The product was removed by filtration, washed with cooled absolute ethanol, recrystallized from methanol and dried. The exploratory and physical data of the structures are recorded in Table 1.

\section{Results and Discussion}

The Schiff base BAPE is formed in good yield by the condensation of acetophenone structure 1 with 1,2-diaminoethane occurred in the 1:1 ratio as in structure 2 (Scheme 1).

Schiff base is crystalline in nature and is soluble in common organic solvents. The metal - ligand complexes were synthesized and obtained in pure form. Reactions of (Cu-, Ni-, Zn-, Co- and Fe- halides) with $\left[\left(\mathrm{N}^{1} \mathrm{Z}, \mathrm{N}^{2} \mathrm{Z}\right)-\mathrm{N}^{1}, \mathrm{~N}^{2}\right.$-bis(1-phenylethylidene) ethane-1,2- diamine] (BAPE) and 4(hydroxyphenyl)tellurium tribromide (OPTB) in 1:2:2 molar ratio in ethanol are represented in Scheme 2. It's formed well defined and crystalline complexes with of $\mathrm{Cu}(\mathrm{II}), \mathrm{Ni}(\mathrm{II}), \mathrm{Co}(\mathrm{II}), \mathrm{Zn}$ (II) and $\mathrm{Fe}(\mathrm{II})$ ions. The results of elemental analysis $(\mathrm{C}, \mathrm{H}, \mathrm{N})$ with molecular formula and the melting points are presented in Table 1. The results obtained are in good agreement with those calculated for the suggested formula and the melting points are sharp, indicating the purity of the prepared Schiff base and their complexes. The structures of the Schiff base and their complexes under study are given below (Scheme 2). The structure of these Schiff bases is also confirmed by IR and ${ }^{1} \mathrm{H}$ NMR spectra, which will be discussed in a detailed manner.

\section{Infrared spectra}

The IR spectra of mixing ligand (BAPE), (OPTB) and their complexes are presented in Table 2. The IR spectra of the ligands and complexes synthesized are shows two strong bands appeared at range (3099-3121) $\mathrm{cm}^{-1}$ and (2861-2931) $\mathrm{cm}^{-1}$ due to stretching aromatic (C-H) and aliphatic (C-H) respectively (Silerstien et al., 2005; Shriner et al., 2004). The IR spectra of the complexes were compared with of the free ligand (BAPE) and (OPTB) in order to determine the coordination sites that may be involved in chelating. There was some guide peaks in the spectra of the ligands, which were helpful in achieving this goal. The position and/or the intensities of these peaks are expected to change upon chelating. New peak is also guide peak, as M-N in chelating. This guide peak are shown in Table 2. Upon comparison This band was shifted to higher or lower wave numbers in the complexes, indicating the participation of the azomethine nitrogen in coordination $(\mathrm{M}-$ N). ${ }^{(42)}$ New bands are found in the spectra of the complexes in the regions $(546-576) \mathrm{cm}^{-1}$ which are assigned to $v(\mathrm{M}-\mathrm{O})$ stretching vibrations for (OPTB) metal complexes. Several medium intensity bands appeared in the $(1492-1575) \mathrm{cm}^{-1}$ region of the spectra are due to the stretching of various $(\mathrm{C}=\mathrm{C})$ vibrations. The IR spectra of the ligand and complexes synthesized are shows two strong bands appeared at range $(1235-1265) \mathrm{cm}^{-1}$ and $(1621-1646) \mathrm{cm}^{-1}$ due to stretching aliphatic $(\mathrm{C}-\mathrm{N})$ and $(\mathrm{C}=\mathrm{N})$ respectively.

The IR spectra of mixes 1-5 and ligand demonstrated a solid band in reach (1182 1195) $\mathrm{cm}-1$ can be credited to $(\mathrm{C}-\mathrm{O})$ security. A wide band in $3515 \mathrm{~cm}-1$ can be alluded to $(\mathrm{O}-\mathrm{H})$ bond in free ligand (OPTB) yet This crest will be vanished in IR spectra of edifices was great and clear confirmation to event of response by hydroxyl bunch in (OPTB) ligand. Accordingly; from the IR spectra it is inferred that the (BAPE) acts as an unbiased bidentate ligand facilitated to the means of azomethine $\mathrm{N}$ while (OPTB) ligand carries on as monodentate and deprotonated hydroxyl bunch. 
Int.J.Curr.Microbiol.App.Sci (2016) 5(8): 545-552

Table.1 Physical and analytical data for complexes 1-5

\begin{tabular}{|c|c|c|c|c|c|c|}
\hline \multirow[t]{2}{*}{ Comp. } & \multirow[t]{2}{*}{ Color } & \multirow[t]{2}{*}{$\begin{array}{c}\text { Melting } \\
\text { point (C) }\end{array}$} & \multicolumn{3}{|c|}{ Analysis $(\%)^{\mathrm{a}}$} & \multirow[t]{2}{*}{ Yield \% } \\
\hline & & & $\mathrm{C}$ & $\mathbf{H}$ & $\mathbf{N}$ & \\
\hline $\mathrm{Cu}(\mathrm{BAPE})_{2}(\mathrm{OPTB})_{2}[1]$ & brown & $210-212$ & $\begin{array}{c}38.15 \\
(38.45)\end{array}$ & $\begin{array}{l}3.20 \\
(3.55)\end{array}$ & $\begin{array}{l}3.71 \\
(3.97)\end{array}$ & 57 \\
\hline $\mathrm{Fe}(\mathrm{BAPE})_{2}(\mathrm{OPTB})_{2}[2]$ & Dark brown & 190-192 & $\begin{array}{c}38.35 \\
(38.81)\end{array}$ & $\begin{array}{c}3.22 \\
(3.65)\end{array}$ & $\begin{array}{c}3.73 \\
(3.90)\end{array}$ & 61 \\
\hline $\mathrm{Zn}(\mathbf{B A P E})_{2}(\mathrm{OPTB})_{2}[3]$ & $\begin{array}{l}\text { Yellowish- } \\
\text { brown }\end{array}$ & 201-203 & $\begin{array}{c}38.11 \\
(38.91)\end{array}$ & $\begin{array}{c}3.20 \\
(3.31)\end{array}$ & $\begin{array}{c}3.70 \\
(3.80)\end{array}$ & 62 \\
\hline $\mathrm{Ni}(\mathrm{BAPE})_{2}(\mathrm{OPTB})_{2}[4]$ & Brown & $235-237$ & $\begin{array}{c}38.28 \\
(38.56)\end{array}$ & $\begin{array}{c}3.21 \\
(3.34)\end{array}$ & $\begin{array}{l}3.72 \\
(3.93)\end{array}$ & 58 \\
\hline $\mathrm{Co}(\mathrm{BAPE})_{2}(\mathrm{OPTB})_{2}[5]$ & brown & $205-207$ & $\begin{array}{c}38.27 \\
(38.79)\end{array}$ & $\begin{array}{c}3.21 \\
(3.10)\end{array}$ & $\begin{array}{c}3.72 \\
(3.55)\end{array}$ & 69 \\
\hline
\end{tabular}

$\overline{\mathrm{a}}$ calculated values are in parentheses

Table.2 IR Spectroscopic data for Ligand and compounds 1-5

\begin{tabular}{|c|c|}
\hline Ligand/ complexes IR $\left(\mathrm{cm}^{-1}\right)$ & $\lambda_{\max }$ in $\mathrm{nm}\left(\varepsilon\right.$ in $\left.\mathrm{M}^{-1} \mathrm{~cm}^{-1}\right)$ \\
\hline BAPE & $\begin{array}{c}3099 \mathrm{~cm}^{-1} v(\mathrm{C}-\mathrm{H}) \text { Ar., } 2931 \mathrm{~cm}^{-1} v(\mathrm{C}-\mathrm{H}) \text { aliph., } 1566 \mathrm{~cm}^{-1} v(\mathrm{C}=\mathrm{C}) \\
\text { Ar., } 1645 \mathrm{~cm}^{-1} v(\mathrm{C}=\mathrm{N}), 1265 \mathrm{~cm}^{-1} v(\mathrm{C}-\mathrm{N}) \text { aliph. }\end{array}$ \\
\hline $\mathrm{Cu}(\mathrm{BAPE})_{2}(\mathrm{OPTB})_{2}[1]$ & $\begin{array}{c}3102 \mathrm{~cm}^{-1} v(\mathrm{C}-\mathrm{H}) \text { Ar., } 2875 \mathrm{~cm}^{-1} v(\mathrm{C}-\mathrm{H}) \text { Aliph., } 1563 \mathrm{~cm}^{-1} v(\mathrm{C}=\mathrm{C}) \\
\text { Ar., } 1192 \mathrm{~cm}^{-1} v(\mathrm{C}-\mathrm{O}) \text { Ar., } 1621 \mathrm{~cm}^{-1} v(\mathrm{C}=\mathrm{N}), 1235 \mathrm{~cm}^{-1} v(\mathrm{C}-\mathrm{N}) \\
\text { Aliph.,435 } \mathrm{cm}^{-1} v(\mathrm{M}-\mathrm{N}), 571 \mathrm{~cm}^{-1} v(\mathrm{M}-\mathrm{O}) .\end{array}$ \\
\hline $\mathrm{Fe}(\mathrm{BAPE})_{2}(\mathrm{OPTB})_{2}[2]$ & $\begin{array}{c}3100 \mathrm{~cm}^{-1} v(\mathrm{C}-\mathrm{H}) \text { Ar., } 2861 \mathrm{~cm}^{-1} v(\mathrm{C}-\mathrm{H}) \text { Aliph., } 1575 \mathrm{~cm}^{-1} v(\mathrm{C}=\mathrm{C}) \\
\text { Ar., } 1182 \mathrm{~cm}^{-1} v(\mathrm{C}-\mathrm{O}) \text { Ar., } 1633 \mathrm{~cm}^{-1} v(\mathrm{C}=\mathrm{N}), 1237 \mathrm{~cm}^{-1} v(\mathrm{C}-\mathrm{N}) \\
\text { Aliph., } 455 \mathrm{~cm}^{-1} v(\mathrm{M}-\mathrm{N}), 546 \mathrm{~cm}^{-1} v(\mathrm{M}-\mathrm{O}) .\end{array}$ \\
\hline $\mathrm{Zn}(\mathrm{BAPE})_{2}(\mathrm{OPTB})_{2}[3]$ & $\begin{array}{c}3012 \mathrm{~cm}^{-1} v(\mathrm{C}-\mathrm{H}) \text { Ar., } 2901 \mathrm{~cm}^{-1} v(\mathrm{C}-\mathrm{H}) \text { Aliph., } 1498 \mathrm{~cm}^{-1} \\
v(\mathrm{C}=\mathrm{C}) \text { Ar., } 1190 \mathrm{~cm}^{-1} v(\mathrm{C}-\mathrm{O}) \text { Ar., } 1647 \mathrm{~cm}^{-1} v(\mathrm{C}=\mathrm{N}), 1239 \mathrm{~cm}^{-1} \\
v(\mathrm{C}-\mathrm{N}) \text { Aliph., } 466 \mathrm{~cm}^{-1} v(\mathrm{M}-\mathrm{N}), 551 \mathrm{~cm}^{-1} v(\mathrm{M}-\mathrm{O}) .\end{array}$ \\
\hline $\mathrm{Ni}(\mathrm{BAPE})_{2}(\mathrm{OPTB})_{2}[4]$ & $\begin{array}{c}3121 \mathrm{~cm}^{-1} v(\mathrm{C}-\mathrm{H}) \text { Ar., } 2910 \mathrm{~cm}^{-1} v(\mathrm{C}-\mathrm{H}) \text { Aliph., } 1492 \mathrm{~cm}^{-1} \\
v(\mathrm{C}=\mathrm{C}) \text { Ar., } 1193 \mathrm{~cm}^{-1} v(\mathrm{C}-\mathrm{O}) \text { Ar., } 1632 \mathrm{~cm}^{-1} v(\mathrm{C}=\mathrm{N}), 1245 \mathrm{~cm}^{-1} \\
v(\mathrm{C}-\mathrm{N}) \text { Aliph., } 455 \mathrm{~cm}^{-1} v(\mathrm{M}-\mathrm{N}), 576 \mathrm{~cm}^{-1} v(\mathrm{M}-\mathrm{O}) .\end{array}$ \\
\hline $\mathrm{Co}(\mathrm{BAPE})_{2}(\mathrm{OPTB})_{2}[5]$ & $\begin{array}{c}3120 \mathrm{~cm}^{-1} v(\mathrm{C}-\mathrm{H}) \text { Ar., } 2895 \mathrm{~cm}^{-1} v(\mathrm{C}-\mathrm{H}) \text { Aliph., } 1545 \mathrm{~cm}^{-1} \\
v(\mathrm{C}=\mathrm{C}) \text { Ar., } 1195 \mathrm{~cm}^{-1} v(\mathrm{C}-\mathrm{O}) \text { Ar., } 1641 \mathrm{~cm}^{-1} v(\mathrm{C}=\mathrm{N}), 1243 \mathrm{~cm}^{-1} \\
v(\mathrm{C}-\mathrm{N}) \text { Aliph., } 462 \mathrm{~cm}^{-1} v(\mathrm{M}-\mathrm{N}), 581 \mathrm{~cm}^{-1} v(\mathrm{M}-\mathrm{O}) .\end{array}$ \\
\hline
\end{tabular}


Scheme.1 Preparative method for base [(N1Z,N2Z)-N1,N2-bis(1-phenylethylidene)ethane-1,2diamine]

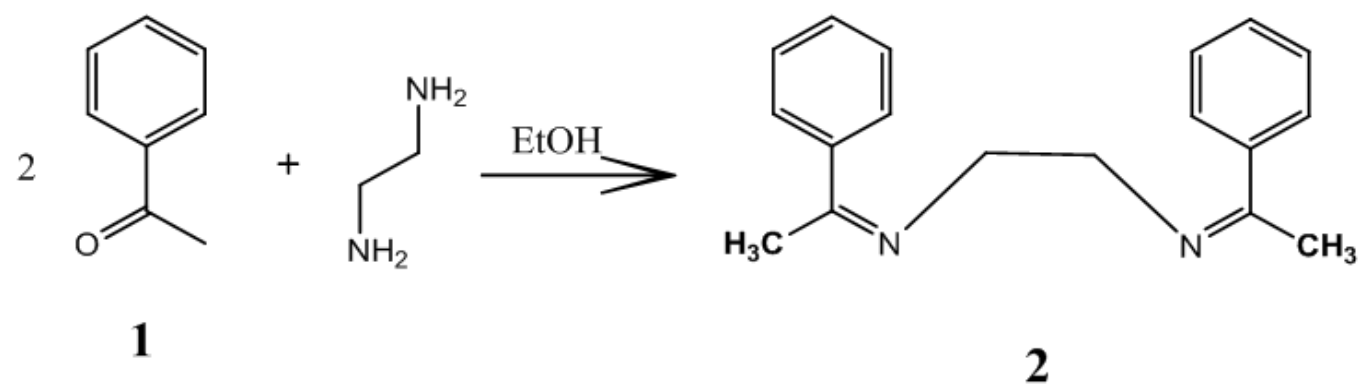

Fig.2 Preparative methods for complexes (1:2:2) molar ratio<smiles>C/C(=N/CC/N=C(/C)c1ccccc1)c1ccccc1</smiles><smiles>CC(C)(C)c1ccc(O)cc1</smiles>

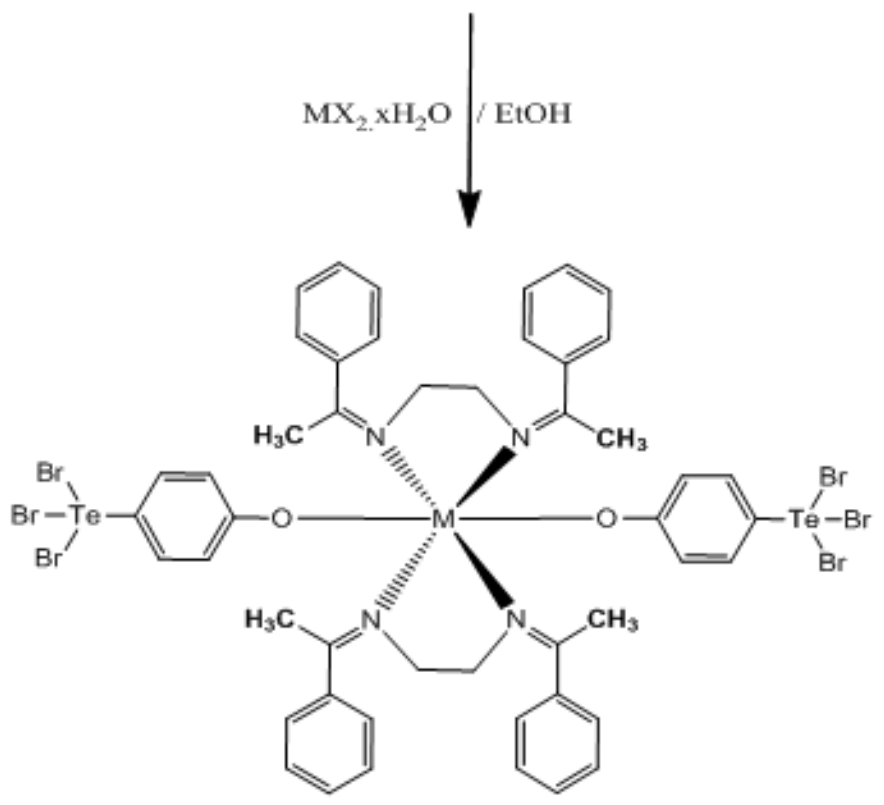

Where $\mathrm{MX}_{2} \times \mathrm{xH}_{2} \mathrm{O}=\mathrm{CuBr}_{2}: \mathrm{NiCl}_{2} 6 \mathrm{H}_{2} \mathrm{O} ; \mathrm{ZnCl}_{2}: \mathrm{CoCl}_{2} 6 \mathrm{H}_{2} \mathrm{O}$ or $\mathrm{FeCl}_{2}$ 
Table.3 1H NMR Spectroscopic data for Ligand and compounds 1-5

\begin{tabular}{|c|c|}
\hline Ligand/ complexes & Chemical shift (ppm) \\
\hline BAPE & $\begin{array}{c}7.31-7.92(\mathrm{~m}, 10 \mathrm{H}, \text { aromatic }), 5.33\left(\mathrm{~s}, 4 \mathrm{H}, \mathrm{CH}_{2}-\mathrm{N}\right), \\
1.96\left(\mathrm{~s}, 6 \mathrm{H}, \mathrm{CH}_{3}\right) .\end{array}$ \\
\hline $\mathrm{Cu}(\mathrm{BAPE})_{2}(\mathrm{OPTB})_{2}[1]$ & $\begin{array}{c}7.35-7.85(\mathrm{~m}, 20 \mathrm{H}, \mathrm{Ar} . \mathrm{PABE}), 6.97-7.32(\mathrm{~m}, 8 \mathrm{H}, \mathrm{Ar} . \\
\text { OPTB }), 3.65\left(\mathrm{~s}, 8 \mathrm{H}, \mathrm{CH}_{2}-\mathrm{N}\right), 1.91\left(\mathrm{~s}, 12 \mathrm{H}, \mathrm{CH}_{3}\right) .\end{array}$ \\
\hline $\mathrm{Fe}(\mathrm{BAPE})_{2}(\mathrm{OPTB})_{2}[2]$ & $\begin{array}{c}7.31-7.89(\mathrm{~m}, 20 \mathrm{H}, \mathrm{Ar} . \mathrm{PABE}), 6.79-7.21(\mathrm{~m}, 8 \mathrm{H}, \mathrm{Ar} . \\
\text { OPTB }), 3.71\left(\mathrm{~s}, 8 \mathrm{H}, \mathrm{CH}_{2}-\mathrm{N}\right), 1.91\left(\mathrm{~s}, 12 \mathrm{H}, \mathrm{CH}_{3}\right) .\end{array}$ \\
\hline $\mathrm{Zn}(\mathrm{BAPE})_{2}(\mathrm{OPTB})_{2}[3]$ & $\begin{array}{c}7.34-7.81(\mathrm{~m}, 20 \mathrm{H}, \mathrm{Ar} . \mathrm{PABE}), 6.91-7.12(\mathrm{~m}, 8 \mathrm{H}, \mathrm{Ar} . \\
\text { OPTB }), 3.63\left(\mathrm{~s}, 8 \mathrm{H}, \mathrm{CH}_{2}-\mathrm{N}\right), 1.90\left(\mathrm{~s}, 12 \mathrm{H}, \mathrm{CH}_{3}\right) .\end{array}$ \\
\hline $\mathrm{Ni}(\mathrm{BAPE})_{2}(\mathrm{OPTB})_{2}[4]$ & $\begin{array}{c}7.31-7.83(\mathrm{~m}, 20 \mathrm{H}, \mathrm{Ar} . \mathrm{PABE}), 6.91-7.22(\mathrm{~m}, 8 \mathrm{H}, \mathrm{Ar} . \\
\text { OPTB }), 3.72\left(\mathrm{~s}, 8 \mathrm{H}, \mathrm{CH}_{2}-\mathrm{N}\right), 1.95\left(\mathrm{~s}, 12 \mathrm{H}, \mathrm{CH}_{3}\right) .\end{array}$ \\
\hline $\mathrm{Co}(\mathrm{BAPE})_{2}(\mathrm{OPTB})_{2}[5]$ & $\begin{array}{c}7.39-7.88(\mathrm{~m}, 20 \mathrm{H}, \mathrm{Ar} . \mathrm{PABE}), 6.93-7.25(\mathrm{~m}, 8 \mathrm{H}, \mathrm{Ar} . \\
\text { OPTB }), 3.87\left(\mathrm{~s}, 8 \mathrm{H}, \mathrm{CH}_{2}-\mathrm{N}\right), 1.90\left(\mathrm{~s}, 12 \mathrm{H}, \mathrm{CH}_{3}\right) .\end{array}$ \\
\hline
\end{tabular}

\section{${ }^{1} \mathrm{H}$ NMR spectra}

${ }^{1} \mathrm{H}$ NMR ghostly information in deturated DMSO arrangement of the integrated mixes are given in Table 1 , The ${ }^{1} \mathrm{H}$ NMR spectra of the Schiff base in DMSO displays multisignals inside the $7.31-7.92 \mathrm{ppm}$ reach are appointed to the sweet-smelling protons of (BAPE) ligand rings and multisignals inside the $6.79-7.32 \mathrm{ppm}$ extent are doled out to the fragrant protons of (OPTB) ligand rings. The spectra of the edifices are inspected in examination with those of the guardian Schiff base. The ${ }^{1} \mathrm{H}$ NMR spectra of the Schiff base integrated from acetophenone and ethylene diamine uncovered a sign at $5.31 \mathrm{ppm}$ (singlet) because of the proton $\mathrm{OH}$ in (OPTB) ligand and The proton $\mathrm{OH}$ has vanished in ${ }^{1} \mathrm{H}$ NMR spectra of edifices, showing that the $\mathrm{OH}$ proton is evacuated by chelation with the metal ion. ${ }^{(43)}$

The spectra of the considerable number of mixes demonstrate a singlet signal at the extent $1.90-1.95 \mathrm{ppm}$ because of the protons $\mathrm{CH}_{3}$ of the (BAPE) ligand in Schiff base and it's buildings. The singlet signals at
$3.63-3.87 \mathrm{ppm}$ recommended the attribution of the proton of the $\mathrm{CH}_{2}-\mathrm{N}$ bunches in (BAPE) ligand while in free ligand has been showed up in $5.33 \mathrm{ppm}$.

In conclusion, another complexes has been set up by the reaction between schiff base (BAPE) as ligand bidntate and organotellurium as monodentate ligand with metal halide. Explanatory IR, ${ }^{1} \mathrm{HNMR}$ and elemental examination $(\mathrm{CHN})$ revealed a $1: 2: 2$ mile ratio in which one of Schiff base, organotellurium and metal halide. In another study will be utilized this edifices as a part of an extensive variety of natural exercises, including anti-infection, hostile to proliferative, calming, and antipyretic properties.

\section{References}

Al-Jadaan, S. A. 1990. M.Sc. Thesis, University of Basrah.

Annapoorani, S., Krishnan, C., 2013, international. J. Chem. Tech. Res., 5(1): 180-185.

Anyfantis, G.C., G.C. Papavassiliou, N. Assimomytis, A. Terzis, V. Psycharis, 
C.P. Raptopoulou, P.K.V. Thoma, I.B. Koutselas. 2008. Solid State Sci., 10: 1729.

Arnold, J. 1995. Prog. Inorg. Chem., 43, 353.

Aumann, K.M., P.J. Scammells, J.M. White, C.H. Schiesser. 2007. Org. Biomol. Chem., 5: 1276.

Babu, P.K., A.M. Lewera, J.H. Chung, R. Hunger, W. Jaegermann, N. AlonsoVante, A. Wieckowski, E. Oldfield. 2007. J. Am. Chem. Soc., 129, 15140.

Bacchi, A., W. Baratta, F. Calderazzo, F. Marchetti, G. Pelizzi. 2002. Inorg. Chem., 41: 3894.

Bochmann, M. 1996. Chem. Vap. Deposition, 2, 85.

Cheng, Y., T.J. Emge, J.G. Brennan. 1996. Inorg. Chem., 35, 7339.

Cimerman, Z., S. Miljanic and N. Galic. 2000. Croatica Chemica Acta, 73: 81.

Davies, R.P., C.V. Francis, A.P.S. Jurd, M.G. Martinelli, A.J.P. White, D.J. Williams. 2004. Inorg. Chem., 43, 4802.

Deyr, K., L. De, S. K. Sen and K. K. Chatterjee, Z. anorg. allg. Chem. 389, 215-219.

Elmali, A., M. Kabak and, Y. Elerman. 2000. J. Mol. Struct., 477: 151.

Fessenden, R.J. and J.S. Fessenden. 1998. Organic Chemistry, Brooks/Cole Publishing Company, USA.

Haddad, R., Yousif, E., Ahmed, A. 2013. Springerplus, 2, 510.

Hine, J. and C.Y. Yeh, 1967. J. Am. Chem. Soc., 89: 2669.

Hirpo, W., S. Dhingra, A.C. Sutorik, M.G. Kanatzidis. 1993. J. Am. Chem. Soc., $115,1597$.

Jones, P.G., M.C.R. de Arellano. J. Chem. Soc., Dalton Trans., 13, 2713.

Kanda, T., L. Engman, I.A. Cotgeave, G. Powis. 1999. J. Org. Chem., 64, 8161.

Kumar, A., M. Agarwal, A.K. Singh. 2008. Polyhedron, 27, 485.
Kunwar, A., B. Mishra, A. Barik, L.B. Kumbhare, R. Pandey, V.K. Jain, K.I. Priyadarsini. 2007. Chem. Res. Toxicol., 20: 1482.

Levason, W., S.D. Orchard, G. Reid. 2002. Coord. Chem. Rev., 225, 159 and references therein.

Ling, J., T.E. Albert-Schmitt. 2007. Inorg. Chem., 46: 5686.

Lloyd, J.R., C.I. Pearce, V.C. Coker, R.A.D. Patrick, G. Van Der Laan, R. Cutting, D.J. Voughan, M. Paterson-Beedle, I.P. Mikhinko, P. Yong, L.E. Macaskie. 2008. Geobiol., 6: 285.

Malik, S., Ghosh, S., Mitu, L., 2011, J. Serb. Chem. Soc., 76(10): 1387-1394.

Mishra, A.P. 1999. J. Indian Chem. Soc., 76, 35-37.

Mugesh, G., W.W. du Mont, H. Sies. 2001. Chem. Rev., 101, 2125 and references therein.

Nishibayashi, Y., J.D. Singh, S. Uemura. Tetrahedron Lett., 35, 3115.

Nishibayashi, Y., J.D. Singh, Y. Arikawa, S. Uemura, M. Hidai. 1997. J. Organomet. Chem., 531, 13.

Nishibayshi, Y., K. Segawa, J.D. Singh, S.I. Fukuzawa, K. Ohe, S. Uemura. 1996. Organometallics, 15, 370.

Pang, H., P.J. Skabara, S. Gordeyev, J.J.W. McDouall, S.J. Coles, M.B. Hursthouse. 2007. Chem. Mater., 19, 301.

Raman, N., Raja, S., Joseph, J., Raja, J., 2007. J. Chil. Chem. Soc., 52(2): 1138-1141.

Shi, M., M. Jiang, L. Liu. 2007. Org. Biomol. Chem., 5, 438.

Shi, Z., D. Zhang, S. Feng, G. Li, Z. Dai, W. $\mathrm{Fu}, \mathrm{X}$. Chen, J. Hua. 2002. J. Chem. Soc., Dalton Trans., 9, 1873.

Shriner, R.I. and C.K. Hermann. 2004. "Spectroscopic Techniques for Organic Chemistry ", John Wiley \& Sons, N.Y. 
Silerstien, R.M., F. X. Webster and D. J. Kiemle, "Spectrometric Identification of Organic Chemistry Compounds ", 6th Ed. , John Wiley \& Sons , N. Y.

Singh, H.B., N. Sudha. 1996. Polyhedron, 15,745 .

Smith, S.M., J.A. Ibers. Coord. Chem. Rev., 200-202, 187.

Soliman A.A., W. Linert. 1999. Thermochimica Acta, 333: 67-75.

Somers, R.C., M.G. Bawendi, D.G. Nocera. 2007. Chem. Soc. Rev., 36, 579.
Steigerwald, M.L., C.R. Sprinkle. 1987. J. Am. Chem. Soc., 109, 7200.

Tiecco, M., L. Testaferri, C. Santi, C. Tomassini, R. Bonini, F. Marini, L. Bagnoli, A. Temperini. 2004. Org. Lett., 6, 4751.

Wirth(Ed.), T. 2000. Modern Developments in Organic Chemistry, in Topics in Current Chemistry, 208, p. 235, Springer-Verlag, Berlin.

Wirth, T. 2000. Angew. Chem. Int. Ed., 39, 3740.

\section{How to cite this article:}

Nuha H. Al-Saadawy, Allaa Kh. Ali and Huda J. Mohammed. 2016. Schiff Base [(N1Z, N2Z)N1, N2-bis (1-Phenylethylidene) ethane-1, 2-diamine] with P-Hydroxyphenyl Telluriumtribromide and their Metal Complexes: Synthesis and Characterization. Int.J.Curr.Microbiol.App.Sci. 5(8): 545-552. doi: http://dx.doi.org/10.20546/ijcmas.2016.508.059 